\title{
Dynamics of Zinc Fractions, Availability to Wheat (Triticum aestivum L.) and Residual Effect on Succeeding Maize (Zea mays L.) in Inceptisols
}

\author{
M. Kumar \& F. M. Qureshi \\ Department of Agricultural Chemistry and Soil Science \\ Rajasthan College of Agriculture, Udaipur \\ Maharana Pratap University of Agriculture and Technology \\ Udaipur, Rajasthan 313 001, India \\ E-mail: mukeshcoabkn@rediffmail.com
}

Received: February 15, 2012 Accepted: February 28, 2012 Online Published: May 7, 2012

doi:10.5539/jas.v4n6p236 URL: http://dx.doi.org/10.5539/jas.v4n6p236

\begin{abstract}
The objective of this study was to compare the transformation, redistribution, availability and relative effectiveness of $\mathrm{Zn}$ from different fertilizer sources viz. Zn-DTPA (Zinc chelated with di-ethylene tri-amine penta-acitic acid), Zn-EDTA (Zinc chelated with ethylene di-amine tetra-acetic acid), Zn-CH (Zinc chelated with a mixture of DTPA \& EDTA) and $\mathrm{ZnSO}_{4} \cdot 7 \mathrm{H}_{2} \mathrm{O}$ (Zinc sulphate hepta hydrate) applied at various zinc levels (5, 10 and $\left.20 \mathrm{mg} \mathrm{kg}^{-1}\right)$ to an Inceptisols in a greenhouse experiment. The results of the greenhouse study showed that the application of three zinc sources significantly increased wheat (Triticum aestivum L.) and succeeding maize (Zea mays L.) dry matter yield and shoot/root ratio compared with the control at increased levels of zinc. Positive, significant correlations were obtained between the zinc concentration in plant and the available zinc as well as the first two sequentially extracted $\mathrm{Zn}$ fractions (water soluble plus exchangeable and organically complexed). The positive and significant effect of zinc levels was also found on plant nitrogen and potassium. The zinc fractions in the soil after harvest of both crops were positively and significantly correlated with each other.
\end{abstract}

Keywords: Dry matter yield, Plant zinc, Zinc fractions

\section{Introduction}

Micronutrients have assumed increasing importance in crop production under present day exploitative agriculture. Intensive cultivation of high yielding varieties and use of high analysis fertilizers disturb the nutrient balance in soil and micronutrients become limiting factor for crop production. Despite their small content, the micronutrients in soil solution are essential to plant nutrition. The availability of the essential micronutrients to plants is often poorly related to their total quantity in the soil. Excluding iron, zinc is the most abundant metal to be found in living organisms, where it plays a major structural, catalytic and co-catalytic role in enzymes. So the study of zinc transformation in soil is an important component of plant nutrition research. The availability of zinc present in the soil or applied as fertilizer is governed by the net effect of a series of physical, chemical and biological reactions in the soil.

Zinc $(\mathrm{Zn})$ is an essential element for plant growth, crop yield and quality. When the supply of plant-available zinc is insufficient, crop yields are reduced and the quality of crop products is frequently impaired (Alloway, 2003). Natural levels of zinc in the soil range from 10 to $300 \mathrm{mg} \mathrm{kg}^{-1}$ with an average of $50 \mathrm{mg} \mathrm{kg}^{-1}$ (Mulligan et al., 2001). It is estimated that 30 per cent of the world's cultivated soils are deficient in zinc (Suzuki et al., 2006). Among cereals, wheat and rice in particular, suffer from zinc deficiency. Grain-yield reductions of up to 80 per cent along with reduced grain zinc level have been observed under zinc deficiency (Cakmak et al., 1998). This has serious implication for human health in countries where consumption of cereal-based diets predominate (Welch, 2001). Further, plants grown on zinc-deficient soils tend to accumulate heavy metals, which again is a potential human health hazard (Hart et al., 1998). Zinc deficiency is a common micronutrient deficiency affecting maize grown in different parts of the world (Kabata-Pendias, 2001). 
Since zinc is essential in plant nutrition, it has to be supplied to crops in some forms for optimum plant growth where zinc deficiency in the soil is expected. In recent years, the use of various zinc fertilizers to correct zinc deficiency has received widespread interest. In general, application of zinc fertilizers to most soils is relatively ineffective, since it is readily converted to unavailable forms. Zinc deficiency is widespread in the soils having high $\mathrm{pH}$, low organic matter and which are calcareous, sodic, sandy and limed acidic in nature (Rattan and Sharma, 2004). The nature and the amount of various forms of zinc depend on the soil texture, $\mathrm{pH}$, calcium carbonate, organic matter and other soil properties (Sharma et al., 2004).

Zinc is known to occur in soil in a number of discrete chemical forms differing in their solubility and thus availability to plants. Further, zinc exists in five distinct pools in soils, namely (a) water soluble (b) exchangeable (c) adsorbed, chelated or complexed (d) held in secondary clay minerals and in metal oxides by occlusions and (e) associated with primary minerals. Water soluble, exchangeable and chelated zinc pools have been considered to be in reversible equilibrium with each other and zinc in these pools is said to be readily available to plants (Viets, 1962). The studies that determine how changes in properties bring zinc into available form are of utmost importance, especially to determine from which form it becomes available and what changes are necessary to cause redistribution. Thus, not only are the forms themselves important, but the potential changes among forms due to outside influences possibly having even greater significance. In other words, nutrient transformation is dynamic in nature, which gives rise to a range of inter-linked nutrient forms. Much of the zinc associated with the solid phase is not available for plant uptake (Lake et al., 1984). Infact, $<10$ per cent, generally is in soluble and exchangeable form.

The continuous application of large amounts of zinc chelates to soil has raised concern regarding the possible accumulation of trace elements and potential harm to the environment, as zinc can be transported downward in soil and may deteriorate ground water quality ( $\mathrm{Li}$ and Shuman, 1997). Hence, its migration, redistribution and leaching needs to be investigated. Soil properties, element characteristics and environmental factors influence zinc concentrations and loads in surface runoff or leachate (He et al., 2004). In general, chelating agents, such as DTPA and EDTA have been shown to contribute largely to zinc movement in soil under conditions of excessive rainfall or irrigation (Alvarez et al., 1996).

The objectives of this study were to determinethe distribution of different factions of zinc in soil and to investigate the effectiveness of the three different types of zinc fertilizers and to determine the relationship between different forms of zinc in soil and zinc content in crop plants by growing wheat and succeeding maize crop.

\section{Materials and Methods}

\subsection{Study Site}

The experiment was conducted for a period of four months (Nov., 2009 to March, 2010) in the greenhouse of the Department of Agricultural Chemistry and Soil Science, Rajasthan College of Agriculture, Udaipur in a sandy clay loam soil (Typic Ustochrepts). The region falls under sub-humid southern plain and Aravali hills (Agro-climatic zone IV-A of Rajasthan) with a typical sub-tropical climate.

\subsection{Pot Experiment}

The experiment was laid out in completely randomized design (CRD) with three replications. $8 \mathrm{~kg}$ of air dried soil was placed in lysimeter pots over washed gravel at the bottom. Soil was treated with different sources of zinc @ 5, 10 and $20 \mathrm{mg} \mathrm{Zn} \mathrm{kg}^{-1}$ (Source: http://www.avachemicals.com/) with treatment combinations $\mathrm{T}_{1}, \mathrm{Zn}_{\mathrm{DTPA}} ; \mathrm{T}_{2}$

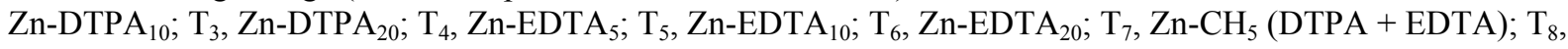
$\mathrm{Zn}-\mathrm{CH}_{10}$ (DTPA + EDTA); T9, Zn-CH 20 (DTPA + EDTA); T10, ZnSO ${ }_{4}-\mathrm{Zn}_{5} ; \mathrm{T}_{11}, \mathrm{ZnSO}_{4}-\mathrm{Zn}_{10}, \mathrm{~T}_{12}, \mathrm{ZnSO}_{4}-\mathrm{Zn}_{20}$ and $\mathrm{T}_{13}, \mathrm{Zn}_{0}$ (control). Basal dose of $\mathrm{N} @ 60 \mathrm{mg} \mathrm{N} \mathrm{kg}{ }^{-1}, \mathrm{P} @ 20 \mathrm{mg} \mathrm{P}_{2} \mathrm{O}_{5} \mathrm{~kg}^{-1}$ and $\mathrm{K} @ 15 \mathrm{mg} \mathrm{K}_{2} \mathrm{O} \mathrm{kg}^{-1}$ for wheat and $\mathrm{N} @ 45 \mathrm{mg} \mathrm{N} \mathrm{kg}^{-1}, \mathrm{P} @ 18 \mathrm{mg} \mathrm{P}_{2} \mathrm{O}_{5} \mathrm{~kg}^{-1}$ and $\mathrm{K} @ 15 \mathrm{mg} \mathrm{K}_{2} \mathrm{O} \mathrm{kg}^{-1}$ for maize were used at the time of sowing. Seven seeds of wheat (Raj-4037) and seven seeds of maize (Pratap Makka Chari-6) were sown per pot (total 39 pots) and maintained three seedlings in each pot after ten days of sowing. The crops were grown for 60 days and harvested. Leaf, stem and root samples were collected and soil samples were also collected after crop harvest and analysed using standard methods of analysis.

\subsection{Soil and Plant Analysis}

The analysed soil having OC, $0.53 \%$ (Piper, 1960); EC, $0.63 \mathrm{dSm}^{-1}$ (Richards, 1954); $\mathrm{CaCO}_{3}, 3.10 \%$ (Hutchinson and Mclennan, 1914); pH, 8.11 (Richards, 1954); available nitrogen, $287.22 \mathrm{~kg} \mathrm{~N} \mathrm{ha}^{-1}$ (Subbiah and Asija, 1956); $\mathrm{P}_{2} \mathrm{O}_{5}, 26.22 \mathrm{~kg} \mathrm{ha}^{-1}$ (Olsen et al., 1954); $\mathrm{K}_{2} \mathrm{O}, 311.56 \mathrm{~kg} \mathrm{ha}^{-1}$ (Richards, 1954); Zn, $0.584 \mathrm{mg} \mathrm{kg}^{-1}$ (Lindsay and Norvell, 1978) and sequentially extracted zinc fractions, WSEX-Zn (Water soluble + exchangeable zinc), 0.497 $\mathrm{mg} \mathrm{kg}^{-1}$ (Shuman, 1985); OC-Zn (Organically complexed zinc), $2.174 \mathrm{mg} \mathrm{kg}^{-1}$ (Shuman, 1985); MnOX-Zn 
(Manganese oxide bound zinc), $0.418 \mathrm{mg} \mathrm{kg}^{-1}$ (Chao, 1972); AFeOX-Zn (Amorphous iron oxide bound zinc), 4.221 (Shuman, 1985); CFeOX-Zn (Crystalline iron oxide bound zinc), $9.473 \mathrm{mg} \mathrm{kg}^{-1}$ (Shuman, 1985); CARB-Zn (Carbonate bound zinc), $1.621 \mathrm{mg} \mathrm{kg}^{-1}$ (Tessier et al., 1979) and RES-Zn (Residual zinc), $123.582 \mathrm{mg} \mathrm{kg}^{-1}$ (Tessier et al., 1979). The plant (leaf, stem and root) samples of both crops (wheat and maize) were also analysed for nitrogen (Snell and Snell, 1959), phosphorus \& potassium (Jackson, 1973) and zinc (Lindsay and Norvell, 1978).

\subsection{Statistical Analysis}

The data of different fractions of zinc were statistically analyzed by using analysis of variance techniques as given by Panse and Sukhatme (1967). Test of significance (T-test) was used for estimation of the treatment differences as described by Cochran and Cox (1959). Critical differences (CD) were calculated to assess the significance between soils wherever they were found significant with F-test. Linear correlation values (r) were computed between various zinc fractions according to procedures as outlined by Snedecor (1961).

\section{Results and Discussion}

\subsection{Dry Matter Yield}

Data presented in the Table 1 showed that the shoot and root dry matter of wheat (60 DAS) significantly increased with increased application of zinc and was respectively, 43 and 33 per cent increased at $20 \mathrm{mg} \mathrm{Zn} \mathrm{kg}{ }^{-1}$ under $\mathrm{Zn}$-DTPA as compared to control while zinc sulphate was less effective as compared to chelated zinc fertilizers in producing shoot and root dry matter (33 and 28 per cent over control at $20 \mathrm{mg} \mathrm{Zn} \mathrm{kg}^{-1}$, respectively). Thus, the data analysis revealed that the shoot/root ratio of both (wheat and maize) crops significantly increased with the application of zinc in soil. These results are in accordance with the findings of Cakmak (2004) and Singh et al. (2004).

Data further showed that residual effect of zinc on dry matter production of shoot and root of fodder maize significantly increased with applied zinc. The dry matter of shoot and root of maize (60 DAS) was respectively, 31 and 21 per cent more at $20 \mathrm{mg} \mathrm{Zn} \mathrm{kg}^{-1}$ level of Zn-DTPA over control, whereas zinc sulphate produced shoot and root dry matter respectively to the extent of 17 and 18 per cent over control. According to Maftoun and Karimian (1989) plants supplied with $\mathrm{Zn}$ produced more stem and leaf's dry weights and contained more $\mathrm{Zn}$ than those grown without $\mathrm{Zn}$. Moreover, $\mathrm{Zn}$-EDTA was generally more effective than $\mathrm{ZnSO}_{4}$ in increasing $\mathrm{Zn}$ concentration and $\mathrm{Zn}$ uptake by stems and leaves. Similar results were also reported by Obrador et al. (2003).

\subsection{Nutrient Content in Plant}

The zinc content in wheat leaves, stem and roots (60 DAS) significantly increased with increased levels of zinc in soil (Tables 2 and 3), similarly, residual effect on zinc content in succeeding maize leaves, stem and roots (60 DAS) was also significant. The zinc content in plant (wheat and maize) varied with application of different $\mathrm{Zn}$ fertilizers and was more with chelated zinc (Zn-DTAP, Zn-EDTA and $\mathrm{Zn}-\mathrm{CH}$ ) than zinc sulphate. Dang et al. (2010) also observed that the concentration of $Z n$ in various above-ground organs of wheat was 9.5 to $112.5 \mathrm{mg}$ $\mathrm{kg}^{-1}$ at different growing stages. All the organs were ordered in such a sequence with respect to $\mathrm{Zn}$ content that leaf blades $>$ spikes $>$ leaf sheaths $>$ stems according to the net absorption and transportation of $\mathrm{Zn}$ as well as their contribution to $\mathrm{Zn}$ accumulation in grains. Vasconcelos et al. (2011) also reported that the zinc concentration in roots and shoots of maize plants were increased by $\mathrm{Zn}$ application both in soil and leaves.

It is revealed from the data (Table 3) that the concentration of $\mathrm{Zn}$ in maize was 2.8 times higher over control when the high $\mathrm{Zn}\left(20 \mathrm{mg} \mathrm{kg}^{-1}\right)$ was applied through the zinc sulphate to previous crop (wheat), this value did not reach $50 \mathrm{mg} \mathrm{kg}^{-1}$ (dry matter), which is given by some authors as the minimum necessary for using this plant (maize) as feeding fodder for ruminant animals (McDonald et al., 1981). However, zinc concentrations of $>50$

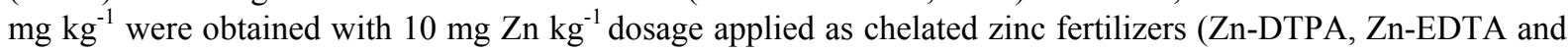
$\mathrm{Zn}-\mathrm{CH}$ ). Srivastava and Gupta (1996) reported the critical limit of zinc deficiency in maize as 20 and $22 \mathrm{mg} \mathrm{Zn}$ $\mathrm{kg}^{-1}$ dry matter of early leaf initial silk and whole plant, respectively. Brennan and Bolland (2002) also reported the critical limit of zinc deficiency in wheat (spring) as $32 \mathrm{mg} \mathrm{Zn} \mathrm{kg}^{-1}$ dry matter of shoot.

The data further showed that nitrogen and potassium content in both crops significantly increased with increased levels of zinc in soil, whereas phosphorus content increased up to $10 \mathrm{mg} \mathrm{Zn} \mathrm{kg}^{-1}$ only and decreased thereafter at increased levels of zinc. These results corroborate to the previous findings of Verma and Minhas (1987) who reported that the $\mathrm{P}$ concentration in wheat and maize plants decreased with the increasing levels of applied zinc. Furthermore, Zhu et al. (2001) also reported that the Zn supply had little effect on tissue P concentration and P uptake per unit of root weight in cultivars under study irrespective of nitrogen supply. An increase in $\mathrm{P}$ availability caused a significant reduction in $\mathrm{Zn}$ uptake per unit of root weight, and tissue concentration of $\mathrm{Zn}$ in cultivars of spring wheat. 


\subsection{Distribution of Zinc Fractions in Soil after Harvest of Crop}

It is evident from the data presented in Tables 4 and 5 that the distribution of different fractions of zinc in soil were significantly affected by zinc sources and found in order: RES $>$ CFeOX $>$ AFeOX $>$ OC $>$ CARB $>$ WSEX $>$ MnOX with all Zn sources at 5 and $10 \mathrm{mg} \mathrm{Zn} \mathrm{kg}^{-1}$ and at $20 \mathrm{mg} \mathrm{Zn} \mathrm{kg}^{-1}$ by zinc sulphate only and same order was also in control, whereas, distribution changed at $20 \mathrm{mg} \mathrm{Zn} \mathrm{kg}^{-1}$ under chelated zinc fertilizers (Zn-DTPA, $\mathrm{Zn}$-EDTA and $\mathrm{Zn}-\mathrm{CH}$ ) and the fractions were in the order: $\mathrm{RES}>>\mathrm{CFeOX}>\mathrm{AFeOX}>\mathrm{OC}>\mathrm{WSEX}>\mathrm{CARB}>$ MnOX after harvest of wheat (60 DAS), similarly, after harvest of maize (60 DAS), the zinc fraction distribution order was same in all treatments. Thus, it could be inferred that WSEX zinc is at optimum levels at $20 \mathrm{mg} \mathrm{Zn} \mathrm{kg}{ }^{-1}$ under chelated zinc fertilizers. Such distribution of zinc fractions depends on many factors viz. fertilizer source, crop type/variety/species and properties of soil etc.

The distribution of $\mathrm{Zn}$ among various chemical forms may vary significantly in response to changing soil properties (Adhikari and Rattan, 2007). Kiekens (1980) stated that there appeared to be two different mechanisms involved in the adsorption of zinc by clays and organic matter. One mechanism operates mainly in acid conditions and is closely related to cation exchange, and the other mechanism operates in alkaline conditions and mainly involves chemisorption and complexation by organic ligands. Apart from reversible adsorption by cation exchange, zinc can also be sorbed irreversibly by lattice penetration in clay minerals. The latter mechanism fixes amounts of zinc in excess of the cation exchange capacity and may be due to sorption of zinc in a hydrolysed form and precipitation of $\mathrm{Zn}(\mathrm{OH})_{2}$. This 'fixation' of zinc tends to increase over time and can affect the long-term availability of zinc fertilisers. At low $\mathrm{pH}, \mathrm{Zn}$ is considered to be held in an exchangeable form at basal planes of clay minerals, whereas at higher $\mathrm{pH}, \mathrm{Zn}$ could be adsorbed by edge sites of clay minerals (McBride, 1994).

Data (Tables 6 and 7) further showed that the zinc fractions in the soil after harvest of wheat (60 DAS) were positively and significantly correlated with each other, whereas correlation coefficient slightly changed with time and was negative and non-significant between WSEX and CARB, CFeOX and DTPA-available, CARB and DTPA-available, while other fractions were positively and significantly correlated. Therefore analysed from the data (Table 8) it can be concluded that positive correlations with higher or lower levels of significance existed between zinc concentration in plant with the extracted fractions, except with the zinc associated with MnOX, $\mathrm{AFeOX}$ and $\mathrm{CFeOX}$. The most positive and meaningful correlations were obtained with WSEX and OC zinc fractions, as well as with the DTPA-extractable $\mathrm{Zn}$ fraction. Similar results were also observed by Behera et al. (2008).

A perusal of the data (Tables 6 and 7) indicated that the DTPA-available zinc in soil significantly increased with increased levels of zinc after harvest of wheat (60 DAS). The residual value of available zinc was also significant after harvest of succeeding fodder maize (60 DAS). Thus, the highest content of available zinc was obtained with chelated zinc fertilizers. The relatively higher maintenance of $\mathrm{Zn}$ in soil due to applied chelated- $\mathrm{Zn}$ may be attributed from the very little or no interaction between soil components preventing various harmful reactions occurring in soil as compared to soil treated with $\mathrm{ZnSO}_{4}$ which enhances greater fixation, adsorption etc., resulting from the greater interaction between soil components (Karak et al., 2005).

The effectiveness of zinc fertilizers was in order: $\mathrm{Zn}$-DTPA $\geq \mathrm{Zn}-\mathrm{CH} \geq \mathrm{Zn}$-EDTA $>\mathrm{ZnSO}_{4}$ after harvest of both (wheat and maize) crops. These results are in accordance with the work of Mehdi et al. (1990) who also reported the relative effectiveness in order as $\mathrm{Zn}$-EDTA $>\mathrm{Zn}\left(\mathrm{NO}_{3}\right)_{2}>\left(\mathrm{NH}_{4}\right)_{2} \mathrm{ZnO}_{2}>\mathrm{ZnSO}_{4}>\mathrm{ZnCl}_{2}$. Karak et al. (2005) also observed that the residual effect of chelated $\mathrm{Zn}$ (Zn-EDTA) in maintaining $\mathrm{Zn}$ in soil was more than that of $\mathrm{ZnSO}_{4}$. Some studies have indicated that organic sources are more effective fertilizers than inorganic ones. Their effectiveness depends on the rate of their disappearance from the soil solution, which is related to their stability (Alloway, 2008). Zinc chelates differ in physical state, chemical reactivity, cost, bioavailability, and susceptibility to leaching. The chelating agents DTPA, HEDTA and EDTA are some of the strongest synthetic chelating agents; in combination with $\mathrm{Zn}$, they form much stronger chelates than naturally occurring organic ligands (Mortvedt and Gilkes, 1993).

Thus, it could be concluded that available zinc content in soil under study was sufficient for both wheat and maize crops that produced dry matter by balanced uptake of other nutrients, such as phosphorus at $10 \mathrm{mg} \mathrm{Zn} \mathrm{kg}{ }^{-1}$ using chelated zinc fertilizers (Zn-DTPA, Zn-EDTA and Zn-CH).

Recent recommendations for the treatment of zinc deficiency in wheat in India are $50 \mathrm{~kg} \mathrm{ha}^{-1}$ zinc sulphate for acute cases and $25 \mathrm{~kg} \mathrm{ha}^{-1}$ for moderate deficiencies (www.krishiworld.com). Kabata-Pendias (2001) listed

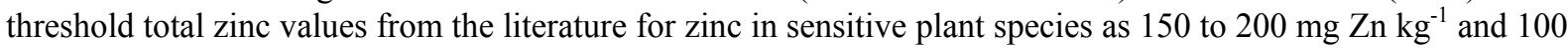


to $500 \mathrm{mg} \mathrm{Zn} \mathrm{kg}^{-1}$ as the range of zinc contents at which the yield of many crops might be reduced by 25 per cent due to toxicity.

\section{Conclusion}

The results obtained in the pot experiment provide an explanation of the differences observed in the $\mathrm{Zn}$ content in leaves, stem and roots of wheat and maize. The application of different levels of $\mathrm{Zn}$ using different $\mathrm{Zn}$ sources significantly increased the dry matter (shoot and root) yield and shoot/root ratio of wheat (60 DAS), as compared to control and significant residual effects of $\mathrm{Zn}$ on dry matter (shoot and root) yield and shoot/root ratio of succeeding fodder maize were also recorded. The $\mathrm{Zn}$ contents in wheat and maize leaves, stem and roots increased significantly with $\mathrm{Zn}$ addition over control. $\mathrm{N}$ and $\mathrm{K}$ content in both crops significantly increased with increased levels of $\mathrm{Zn}$. The distributions of different fractions of $\mathrm{Zn}$ in soil were also influenced by the sources of $\mathrm{Zn}$ and their levels. Different fractions of $\mathrm{Zn}$ in soil were positively and significantly correlated with each other after harvest of wheat (60 DAS), whereas correlation coefficient slightly changed with time and was negative and non-significant between WSEX and CARB, CFeOX and DTPA-available, CARB and DTPA-available, while other fractions were positively and significantly correlated. The effectiveness of $\mathrm{Zn}$ fertilizers were in order: $\mathrm{Zn}-\mathrm{DTPA} \geq \mathrm{Zn}-\mathrm{CH} \geq \mathrm{Zn}-\mathrm{EDTA}>\mathrm{ZnSO}_{4} .7 \mathrm{H}_{2} \mathrm{O}$ after harvest of both (wheat and maize) crops. The available zinc content in soil was sufficient for both crops (wheat and maize) that produced dry matter through balanced uptake of other nutrients, such as phosphorus at $10 \mathrm{mg} \mathrm{Zn} \mathrm{kg}^{-1}$ using chelated zinc fertilizers (Zn-DTPA, Zn-EDTA and Zn-CH).

\section{References}

Adhikari, T., \& Rattan, R. K. (2007). Distribution of zinc fractions in some major soils of India and the impact on nutrition of rice. Communications in Soil Science and Plant Analysis, 38, 2779-2798. http://dx.doi.org/10.1080/00103620701663032

Alloway, B. J. (2008). Zinc in soils and crop nutrition. International Zinc Association, Brussels, http://www.iza.com

Alloway, B. J. (2003). Zinc in soils and crop nutrition. International Zinc Association, 114, $\mathrm{http} / / \mathrm{www}$. zinc-crops.org

Alvarez, J. M., Rico, M. I., \& Obrador, A. (1996). Lixiviation and extraction of zinc in a calcareous soil treated with zinc-chelated fertilizers. Journal of Agricultural and Food Chemistry, 44, 3383-3387. http://dx.doi.org/10.1021/jf9506444

Behera, S. K., Singh, D., Dwivedi, B. S., Singh, S., Kumar, K., \& Rana, D. S. (2008). Distribution of fractions of zinc and their contribution towards availability and plant uptake of zinc under long-term maize (Zea mays L.) wheat (TriticumaestivumL.) cropping on an Inceptisol. Australian Journal of Soil Research, 46, 83-89. http://dx.doi.org/10.1071/SR07073

Brennan, R. F., \& Bolland, M. D. A. (2002). Relative effectiveness of soil-applied zinc for four crop species. Australian Journal of Experimental Agriculture, 42, 985-993. http://dx.doi.org/10.1071/EA01154

Cakmak, I. (2004). Identification and correction of widespread zinc deficiency in Turkey - a success story (a NATO-Science for Stability Project). Proceedings of the International Fertiliser Society, 552, 1-26.

Cakmak, I., Torun, B., Erenoğlu, B., Öztürk, L., Marschner, H., Kalayci, M., Ekiz, H., \& Yilmaz, A. (1998). Morphological and physiological differences in the response of cereals to zinc deficiency. Euphytica, 100, 349-357. http://dx.doi.org/10.1023/A:1018318005103

Chao, T. T. (1972). Selective dissolution of manganese oxides from soils and sediments with acidified hydroxylamine hydrochloride. Soil Science Society of America Journal, 36, 764-768. http://dx.doi.org/10.2136/sssaj1972.03615995003600050024x

Cochran, W. G., \& Cox, G. M. (1959). Experimental designs. John Wiley and Sons, New York.

Dang, H., Li, R., Sun, Y., Zhang, X., \& Li, Y. (2010). Absorption, Accumulation and Distribution of Zinc in Highly-Yielding Winter Wheat. Agricultural Sciences in China, 9, 965-973. http://dx.doi.org/10.1016/S1671-2927(09)60178-4

Hart, J. J., Norvell, W. A., Welch, R. M., Sullivan, L. A., \& Kochian L. V. (1998). Characterization of zinc uptake, binding, and translocation of bread and durum wheat cultivars. Plant Physiology, 118, $219-226$. http://dx.doi.org/10.1104/pp.118.1.219 
He, Z. L., Zhang, M. K., Calvert, D. V., Stoffella, P. J., Yang, X. E., \& Yu, S. (2004). Transport of heavy metals in surface runoff from vegetable and citrus fields in Florida, USA. Soil Science Society of America Journal, 68 , 1662-1669. http://dx.doi.org/10.2136/sssaj2004.1662

Hutchinson, H. B., \& McLennan, K. J. (1914). The Determination of Soil Carbonates. The Journal of Agricultural Science, 6, 323-327. http://dx.doi.org/10.1017/S0021859600001866

Jackson, M. L. (1973). Soil chemical analysis. Prentice Hall of India (P) Ltd., New Delhi.

Kabata-Pendias, A. (2001). Trace elements in soils and plants (3rd ed.). CRC Press, Boca Raton, Fl. 413.

Karak, T., Singh, U. K., Das, S., Das, D. K., \& Kuzyakov, Y. (2005). Comparative efficacy of $\mathrm{ZnSO}_{4}$ and Zn-EDTA application for fertilization of rice (Oryza sativa L.). Archives of Agronomy and Soil Science, 51, 253-264. http://dx.doi.org/10.1080/03650340400026701

Kiekens, L. (1980). Absorptieverschijnselen van zwaremetalen in gronden. Doctoral Thesis, University of Gent.

Lake, D. L., Kirk, P. W. W., \& Lester, J. N. (1984). Fractionation, characterization and speciation of heavy metals in sewage sludge and sludge amended soils: A Review. Journal of Environmental Quality, 13, 175-183. http://dx.doi.org/10.2134/jeq1984.00472425001300020001x

Li, Z., \& Shuman, L. M. (1997). Mobility of $\mathrm{Zn}, \mathrm{Cd}$ and $\mathrm{Pb}$ in soils as affected by poultry litter extract-I. Leaching in soil columns. Environmental Pollution, 95, 219-226. http://dx.doi.org/10.1016/S0269-7491(96)00077-2

Lindsay, W. L., \& Norvell, W. A. (1978). Development of DTPA soil test for zinc, iron, manganese and copper. Soil Science Society of America Journal, $42,428$. http://dx.doi.org/10.2136/sssaj1978.03615995004200030009x

Maftoun, M., \& Karimian, N. (1989). Relative efficiency of two zinc sources for maize (Zea mays L.) in two calcareous soils from an arid area of Iran. Agronomie, 9, 771-775. http://dx.doi.org/10.1051/agro:19890804

McBride, M. B. (1994). Environmental chemistry of soils. New York: Oxford Uni. Pr.

McDonald, P., Edwards, R. A., \& Greenhalgh, J. F. D. (1981). Innutricio' n animal (3rd ed.). Acribia, Zaragoza, Spain. p. 497.

Mehdi, S. M., Ranjah, A. M., \& Hussain, T. (1990). Relative efficiency of various sources of zinc. Sarhad Journal of Agriculture, 6, 103-106.

Mortvedt, J. J., \& Gilkes, R. J. (1993). Zinc fertilizers. In A. D. Robson (ed.), Zinc in soils and plants. Developments in Plant and Soil Science 55 (pp. 33-34). Kluwer Academic Publ., Dordrecht, Netherland.

Mulligan, C. N., Yong, R. N., \& Gibbs, B. F. (2001). Remediation technologies for metal-contaminated soils

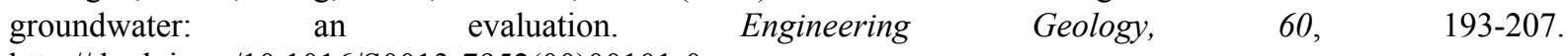
http://dx.doi.org/10.1016/S0013-7952(00)00101-0

Obrador, A., Novillo, J., \& Alvarez, J. M. (2003). Mobility and availability to plants of two sources applied to a calcareous soil. Soil Science Society of America Journal, 67, 564-572. http://dx.doi.org/10.2136/sssaj2003.0564

Olsen, S. R., Cole, C. V., Watanable, F. S., \& Dean, L. A. (1954). Estimation of available phosphorus in soil by extraction with sodium bicarbonate. Circular, USDA, Washington, DC. 939.

Panse, V. G., \& Sukhatme, P. V. (1967). Statistical methods for agricultural workers. ICAR, New Delhi.

Piper, C. S. (1960). Soil and plant analysis. Hans Publishers, Bombay, India.

Rattan, R. K., \& Sharma, P. D. (2004). Main micronutrients available and their method of use. Proceedings IFA International Symposium on Micronutrients, 1-10.

Richards, L. A. (1954). Diagnosis and improvement of saline and alkali soils. USDA Hand Book, No. 60, U.S. Department of Agriculture, Washington DC.

Sharma, B. D., Arora, H., Kumar, R., \& Nayyar, V. K. (2004). Relationships between soil characteristics and total and DTPA-extractable micronutrients in Inceptisols of Punjab. Communications in Soil Science and Plant Analysis, 35, 799-818. http://dx.doi.org/10.1081/CSS-120030359

Shuman, L. M. (1985). Fractionation method for soil micronutrients. Soil Science, 140, 11-22. http://dx.doi.org/10.1097/00010694-198507000-00003

Singh, S., Dave, P. V., Choudhary, S. S., \& Swami, B. N. (2004). Performance of wheat under different levels of phosphorus and zinc in Inceptisol and Vertisol. Journal of Soils and Crops, 14, 465-468. 
Snedecor, G. W. (1961). Statistical methods. Allied Pacific Pvt. Ltd., Bombay.

Snell, F. D., \& Snell, C. T. (1959). Colorimetric methods of analysis (3rd ed. vol. IID.). Van Nostrand Inc. New York.

Srivastava, P. C., \& Gupta, U. C. (1996). Trace Elements in Crop Production. Science Publishers, Lebanon, New Hampshire, 356.

Subbiah, B. V., \& Asija, G. L. (1956). A Rapid Procedure for the Estimation of Available Nitrogen in Soils. Current Science, 25, 259-260.

Suzuki, M., Takahashi, M., Tsukamoto, T., Watanabe, S., Matsuhashi, S., Yazaki, J., Kishimoto, N., Kikuchi, S., Nakanishi, H. Mori, S., \& Nishizawa, N. K. (2006). Biosynthesis and secretion of mugineic acid family phytosiderophores in zinc-deficient barley. The Plant Journal, 48, 85-97. http://dx.doi.org/10.1111/j.1365-313X.2006.02853.x

Tessier, A., Campbell, P. G. C., \& Bisson, M. (1979). Sequential extraction procedure for the speciation of particulate trace metals. Analytical Chemistry, 51, 844-851. http://dx.doi.org/10.1021/ac50043a017

Vasconcelos, A. C. F., Nascimento, C. W. A., \& Filho, F. F. C. (2011). Distribution of zinc in maize plants as a function of soil and foliar Zn supply. International Research Journal of Agricultural Science, 1, 1-5.

Verma, T. S., \& Minhas, R. S. (1987). Zinc and phosphorus interaction in a wheat- maize cropping system. Fertilizer Research, 13, 77-86. http://dx.doi.org/10.1007/BF01049804

Viets, F. G. (1962). Chemistry and availability of micronutrients in soils. Journal of Agricultural and Food Chemistry, 10, 174-178. http://dx.doi.org/10.1021/jf60121a004

Welch, R. M. (2001). Impact of mineral nutrients in plants on human nutrition on a worldwide scale. In Horst, W. J. et al. (Ed.) Plant Nutrition - Food Security and Sustainability of Agro-ecosystems (pp. 284-285). Kluwer, Dordrecht, Netherland.

Zhu, Y. G., Smith, S. E., \& Smith, F. A. (2001). Zinc (Zn)-phosphorus (P) Interactions in Two Cultivars of Spring Wheat (Triticumaestivum L.) Differing in P Uptake Efficiency. Annals of Botany, 88, 941-945. http://dx.doi.org/10.1006/anbo.2001.1522

Table 1. Effect of different levels of zinc and zinc sources on dry matter yield $\left(\mathrm{g} \mathrm{pot}^{-1}\right)$ and root shoot : ratio of wheat and its residual effect on succeeding maize

\begin{tabular}{ccccccc}
\hline \multirow{2}{*}{ Treatments } & \multicolumn{3}{c}{ Wheat (60 DAS) } & \multicolumn{3}{c}{ Maize (60 DAS) } \\
\cline { 2 - 7 } & Shoot & Roots & Shoot : Root Ratio & Shoot & Roots & Shoot : Root Ratio \\
\hline $\mathrm{T}_{1}$ & 15.380 & 8.857 & 1.736 & 17.094 & 9.900 & 1.727 \\
$\mathrm{~T}_{2}$ & 16.397 & 9.077 & 1.806 & 17.837 & 10.080 & 1.770 \\
$\mathrm{~T}_{3}$ & 16.713 & 9.190 & 1.819 & 18.100 & 10.163 & 1.781 \\
$\mathrm{~T}_{4}$ & 15.230 & 8.823 & 1.726 & 17.027 & 9.893 & 1.721 \\
$\mathrm{~T}_{5}$ & 16.200 & 9.063 & 1.787 & 17.680 & 10.070 & 1.756 \\
$\mathrm{~T}_{6}$ & 16.477 & 9.163 & 1.798 & 17.893 & 10.150 & 1.763 \\
$\mathrm{~T}_{7}$ & 15.323 & 8.820 & 1.737 & 17.050 & 9.910 & 1.721 \\
$\mathrm{~T}_{8}$ & 16.287 & 9.090 & 1.792 & 17.843 & 10.043 & 1.777 \\
$\mathrm{~T}_{9}$ & 16.600 & 9.180 & 1.808 & 18.060 & 10.157 & 1.778 \\
$\mathrm{~T}_{10}$ & 14.780 & 8.507 & 1.738 & 15.850 & 9.607 & 1.650 \\
$\mathrm{~T}_{11}$ & 15.337 & 8.763 & 1.750 & 16.120 & 9.757 & 1.652 \\
$\mathrm{~T}_{12}$ & 15.567 & 8.867 & 1.755 & 16.273 & 9.847 & 1.653 \\
$\mathrm{~T}_{13}$ & 11.663 & 6.923 & 1.707 & 13.870 & 8.380 & 1.658 \\
$\mathrm{SEm} \pm$ & 0.2421 & 0.1682 & 0.0237 & 0.2767 & 0.1885 & 0.0157 \\
$\mathrm{CD}(\mathrm{p}=0.05)$ & 0.7036 & 0.4891 & 0.0690 & 0.8045 & 0.5479 & 0.0457 \\
\hline
\end{tabular}

Where, DAS=Days After Sowing. 
Table 2. Effect of different levels of zinc and zinc sources on content of N, P, K and Zn in wheat (60 DAS)

\begin{tabular}{|c|c|c|c|c|c|c|c|c|c|c|c|c|}
\hline \multirow{2}{*}{ Treatments } & \multicolumn{3}{|c|}{ Nitrogen (\%) } & \multicolumn{3}{|c|}{ Phosphorus (\%) } & \multicolumn{3}{|c|}{ Potassium (\%) } & \multicolumn{3}{|c|}{ Zinc $\left(\mathrm{mg} \mathrm{kg}^{-1}\right)$} \\
\hline & Leaves & Stem & Roots & Leaves & Stem & Roots & Leaves & Stem & Roots & Leaves & Stem & Roots \\
\hline $\mathrm{T}_{1}$ & 1.524 & 1.469 & 1.442 & 0.197 & 0.195 & 0.194 & 1.191 & 1.123 & 1.088 & 58.977 & 61.120 & 65.460 \\
\hline $\mathrm{T}_{2}$ & 1.561 & 1.511 & 1.494 & 0.191 & 0.189 & 0.188 & 1.226 & 1.161 & 1.134 & 70.637 & 72.350 & 76.783 \\
\hline $\mathrm{T}_{3}$ & 1.591 & 1.534 & 1.526 & 0.184 & 0.182 & 0.180 & 1.264 & 1.191 & 1.172 & 79.893 & 81.480 & 85.490 \\
\hline $\mathrm{T}_{4}$ & 1.515 & 1.463 & 1.434 & 0.196 & 0.194 & 0.193 & 1.185 & 1.128 & 1.104 & 59.277 & 61.250 & 65.813 \\
\hline $\mathrm{T}_{5}$ & 1.571 & 1.502 & 1.477 & 0.190 & 0.188 & 0.187 & 1.222 & 1.172 & 1.142 & 69.643 & 71.470 & 75.487 \\
\hline $\mathrm{T}_{6}$ & 1.596 & 1.538 & 1.519 & 0.185 & 0.183 & 0.181 & 1.274 & 1.204 & 1.161 & 78.950 & 80.674 & 84.150 \\
\hline $\mathrm{T}_{7}$ & 1.523 & 1.466 & 1.435 & 0.198 & 0.196 & 0.195 & 1.201 & 1.139 & 1.107 & 59.983 & 62.537 & 66.470 \\
\hline $\mathrm{T}_{8}$ & 1.577 & 1.511 & 1.491 & 0.191 & 0.189 & 0.187 & 1.242 & 1.174 & 1.146 & 69.980 & 73.470 & 77.577 \\
\hline $\mathrm{T}_{9}$ & 1.601 & 1.539 & 1.523 & 0.184 & 0.182 & 0.181 & 1.284 & 1.199 & 1.182 & 78.740 & 81.450 & 85.943 \\
\hline $\mathrm{T}_{10}$ & 1.478 & 1.421 & 1.424 & 0.196 & 0.193 & 0.186 & 1.173 & 1.125 & 1.073 & 40.617 & 42.240 & 47.237 \\
\hline $\mathrm{T}_{11}$ & 1.543 & 1.463 & 1.464 & 0.191 & 0.188 & 0.185 & 1.214 & 1.147 & 1.124 & 51.737 & 53.740 & 58.583 \\
\hline $\mathrm{T}_{12}$ & 1.581 & 1.492 & 1.491 & 0.183 & 0.181 & 0.180 & 1.247 & 1.184 & 1.158 & 59.280 & 61.560 & 66.480 \\
\hline $\mathrm{T}_{13}$ & 1.418 & 1.351 & 1.325 & 0.186 & 0.185 & 0.183 & 1.151 & 1.097 & 1.067 & 18.640 & 20.457 & 23.130 \\
\hline $\operatorname{SEm} \pm$ & 0.0191 & 0.0201 & 0.0208 & 0.0018 & 0.0013 & 0.0013 & 0.0154 & 0.0136 & 0.0119 & 1.1655 & 0.8576 & 1.1703 \\
\hline $\mathrm{CD}(\mathrm{p}=0.05)$ & 0.0554 & 0.0585 & 0.0604 & 0.0054 & 0.0038 & 0.0039 & 0.0448 & 0.0394 & 0.0346 & 3.3879 & 2.4929 & 3.4020 \\
\hline
\end{tabular}

Where, DAS=Days After Sowing.

Table 3. Residual effect of different levels of zinc and zinc sources on content of N, P, K and $\mathrm{Zn}$ in maize (60 DAS)

\begin{tabular}{|c|c|c|c|c|c|c|c|c|c|c|c|c|}
\hline \multirow[t]{2}{*}{ Treatments } & \multicolumn{3}{|c|}{ N (\%) } & \multicolumn{3}{|c|}{ P (\%) } & \multicolumn{3}{|c|}{ K (\%) } & \multicolumn{3}{|c|}{$\mathrm{Zn}\left(\mathrm{mg} \mathrm{kg}^{-1}\right)$} \\
\hline & Leaves & Stem & Roots & Leaves & Stem & Roots & Leaves & Stem & Roots & Leaves & Stem & Roots \\
\hline $\mathrm{T}_{1}$ & 1.377 & 1.315 & 1.280 & 0.201 & 0.199 & 0.197 & 1.230 & 1.200 & 1.191 & 46.753 & 48.150 & 53.507 \\
\hline $\mathrm{T}_{2}$ & 1.408 & 1.352 & 1.312 & 0.197 & 0.195 & 0.194 & 1.250 & 1.220 & 1.210 & 57.220 & 59.180 & 64.240 \\
\hline $\mathrm{T}_{3}$ & 1.425 & 1.374 & 1.330 & 0.191 & 0.189 & 0.189 & 1.260 & 1.230 & 1.231 & 65.447 & 67.593 & 71.137 \\
\hline $\mathrm{T}_{4}$ & 1.379 & 1.318 & 1.274 & 0.202 & 0.200 & 0.198 & 1.230 & 1.200 & 1.202 & 46.247 & 48.470 & 52.350 \\
\hline $\mathrm{T}_{5}$ & 1.409 & 1.352 & 1.316 & 0.198 & 0.196 & 0.194 & 1.250 & 1.210 & 1.214 & 57.483 & 59.240 & 63.240 \\
\hline $\mathrm{T}_{6}$ & 1.427 & 1.378 & 1.334 & 0.192 & 0.189 & 0.189 & 1.260 & 1.220 & 1.224 & 66.470 & 68.480 & 72.480 \\
\hline $\mathrm{T}_{7}$ & 1.381 & 1.321 & 1.280 & 0.202 & 0.200 & 0.198 & 1.240 & 1.200 & 1.190 & 47.180 & 49.480 & 52.860 \\
\hline $\mathrm{T}_{8}$ & 1.418 & 1.355 & 1.317 & 0.197 & 0.195 & 0.193 & 1.250 & 1.210 & 1.211 & 57.417 & 58.950 & 63.337 \\
\hline $\mathrm{T}_{9}$ & 1.425 & 1.367 & 1.335 & 0.191 & 0.189 & 0.190 & 1.270 & 1.220 & 1.218 & 65.947 & 68.160 & 70.893 \\
\hline $\mathrm{T}_{10}$ & 1.375 & 1.315 & 1.260 & 0.200 & 0.198 & 0.197 & 1.230 & 1.190 & 1.192 & 35.510 & 36.220 & 39.213 \\
\hline $\mathrm{T}_{11}$ & 1.405 & 1.343 & 1.290 & 0.199 & 0.196 & 0.195 & 1.230 & 1.200 & 1.203 & 42.893 & 43.670 & 46.557 \\
\hline $\mathrm{T}_{12}$ & 1.416 & 1.361 & 1.310 & 0.193 & 0.191 & 0.189 & 1.250 & 1.210 & 1.209 & 47.540 & 48.950 & 51.650 \\
\hline $\mathrm{T}_{13}$ & 1.362 & 1.313 & 1.250 & 0.193 & 0.192 & 0.191 & 1.220 & 1.190 & 1.185 & 16.757 & 18.250 & 20.540 \\
\hline $\operatorname{SEm} \pm$ & 0.0156 & 0.0151 & 0.0148 & 0.0019 & 0.0013 & 0.0012 & 0.0094 & 0.0062 & 0.0096 & 0.8309 & 0.7460 & 0.7365 \\
\hline $\begin{array}{l}\mathrm{CD}(\mathrm{p}= \\
0.05)\end{array}$ & 0.0453 & 0.0440 & 0.0432 & 0.0056 & 0.0038 & 0.0034 & 0.0273 & 0.0180 & 0.0280 & 2.4153 & 2.1686 & 2.1409 \\
\hline
\end{tabular}

Where, DAS=Days After Sowing. 
Table 4. Effect of different levels of zinc and zinc sources on fractions of zinc $\left(\mathrm{mg} \mathrm{kg}^{-1}\right)$ in soil after harvest of wheat (60 DAS)

\begin{tabular}{ccccccccc}
\hline Treatments & WSEX & OC & MnOX & AFeOX & CFeOX & CARB & RES & $\begin{array}{c}\text { DTPA- } \\
\text { Available }\end{array}$ \\
\hline $\mathrm{T}_{1}$ & 1.680 & 2.200 & 0.433 & 4.147 & 9.273 & 1.917 & 124.650 & 1.865 \\
$\mathrm{~T}_{2}$ & 2.017 & 2.390 & 0.520 & 4.350 & 9.383 & 2.120 & 126.237 & 2.385 \\
$\mathrm{~T}_{3}$ & 2.377 & 2.520 & 0.633 & 4.503 & 9.637 & 2.240 & 127.683 & 3.088 \\
$\mathrm{~T}_{4}$ & 1.663 & 2.207 & 0.417 & 4.157 & 9.277 & 1.907 & 124.320 & 1.858 \\
$\mathrm{~T}_{5}$ & 1.987 & 2.367 & 0.520 & 4.337 & 9.403 & 2.113 & 126.140 & 2.363 \\
$\mathrm{~T}_{6}$ & 2.387 & 2.530 & 0.637 & 4.510 & 9.587 & 2.200 & 127.273 & 3.075 \\
$\mathrm{~T}_{7}$ & 1.680 & 2.203 & 0.420 & 4.160 & 9.275 & 1.917 & 124.277 & 1.867 \\
$\mathrm{~T}_{8}$ & 1.977 & 2.380 & 0.530 & 4.344 & 9.343 & 2.110 & 125.153 & 2.375 \\
$\mathrm{~T}_{9}$ & 2.377 & 2.527 & 0.640 & 4.500 & 9.637 & 2.213 & 127.287 & 3.075 \\
$\mathrm{~T}_{10}$ & 1.353 & 2.187 & 0.530 & 4.145 & 9.280 & 1.983 & 124.783 & 1.344 \\
$\mathrm{~T}_{11}$ & 1.967 & 2.360 & 0.613 & 4.335 & 9.410 & 2.197 & 126.450 & 1.785 \\
$\mathrm{~T}_{12}$ & 2.167 & 2.517 & 0.670 & 4.493 & 9.647 & 2.287 & 129.150 & 2.109 \\
$\mathrm{~T}_{13}$ & 0.480 & 2.145 & 0.403 & 4.143 & 9.193 & 1.577 & 123.546 & 0.538 \\
$\mathrm{SEm} \pm$ & 0.0207 & 0.0285 & 0.0077 & 0.0352 & 0.1086 & 0.0378 & 1.1487 & 0.0292 \\
$\mathrm{CD}(\mathrm{p}=0.05)$ & 0.0602 & 0.0829 & 0.0223 & 0.1024 & 0.3156 & 0.1098 & 3.3392 & 0.0850 \\
\hline
\end{tabular}

Where, DAS=Days After Sowing, WSEX $=$ Water soluble + exchangeable zinc, OC=Organically complexed zinc, $\mathrm{MnOX}=$ Manganese oxide bound zinc, $\mathrm{AFeOX}=\mathrm{Amorphous}$ iron oxide bound zinc, $\mathrm{CFeOX}=$ Crystalline iron oxide bound zinc, $\mathrm{CARB}=$ Carbonate bound zinc, $\mathrm{RES}=\mathrm{Residual}$ zinc.

Table 5. Residual effect of different levels of zinc and zinc sources on fractions of zinc $\left(\mathrm{mg} \mathrm{kg}^{-1}\right)$ in soil after harvest of maize (60 DAS)

\begin{tabular}{ccccccccc}
\hline Treatments & WSEX & OC & MnOX & AFeOX & CFeOX & CARB & RES & DTPA-Available \\
\hline $\mathrm{T}_{1}$ & 1.580 & 2.180 & 0.320 & 3.810 & 9.060 & 1.730 & 126.450 & 1.540 \\
$\mathrm{~T}_{2}$ & 1.823 & 2.320 & 0.410 & 3.910 & 9.120 & 2.083 & 129.140 & 1.920 \\
$\mathrm{~T}_{3}$ & 1.910 & 2.470 & 0.470 & 3.990 & 9.180 & 2.103 & 131.450 & 2.335 \\
$\mathrm{~T}_{4}$ & 1.573 & 2.170 & 0.330 & 3.790 & 9.080 & 1.730 & 126.480 & 1.532 \\
$\mathrm{~T}_{5}$ & 1.807 & 2.310 & 0.420 & 3.900 & 9.127 & 2.080 & 129.123 & 1.915 \\
$\mathrm{~T}_{6}$ & 1.880 & 2.480 & 0.470 & 3.990 & 9.170 & 2.097 & 131.470 & 2.318 \\
$\mathrm{~T}_{7}$ & 1.587 & 2.170 & 0.320 & 3.810 & 9.060 & 1.730 & 125.840 & 1.542 \\
$\mathrm{~T}_{8}$ & 1.787 & 2.315 & 0.410 & 3.900 & 9.130 & 2.080 & 128.657 & 1.916 \\
$\mathrm{~T}_{9}$ & 1.823 & 2.500 & 0.490 & 3.990 & 9.187 & 2.107 & 130.677 & 2.325 \\
$\mathrm{~T}_{10}$ & 1.260 & 2.182 & 0.380 & 4.020 & 9.547 & 1.870 & 126.510 & 1.236 \\
$\mathrm{~T}_{11}$ & 1.660 & 2.330 & 0.450 & 4.180 & 9.687 & 2.181 & 129.907 & 1.461 \\
$\mathrm{~T}_{12}$ & 1.793 & 2.510 & 0.520 & 4.320 & 9.810 & 2.240 & 131.843 & 1.813 \\
$\mathrm{~T}_{13}$ & 0.430 & 1.940 & 0.382 & 3.720 & 9.123 & 1.470 & 123.949 & 0.526 \\
$\mathrm{SEm} \pm$ & 0.0383 & 0.0533 & 0.0084 & 0.0799 & 0.0654 & 0.0283 & 1.7509 & 0.0114 \\
$\mathrm{CD}(\mathrm{p}=0.05)$ & 0.1114 & 0.1549 & 0.0245 & 0.2323 & 0.1900 & 0.0823 & 5.0899 & 0.0331 \\
\hline
\end{tabular}

Where, DAS=Days After Sowing, WSEX=Water soluble + exchangeable zinc, $\mathrm{OC}=$ Organically complexed zinc, $\mathrm{MnOX}=$ Manganese oxide bound zinc, $\mathrm{AFeOX}=\mathrm{Amorphous}$ iron oxide bound zinc, $\mathrm{CFeOX}=\mathrm{Crystalline}$ iron oxide bound zinc, $\mathrm{CARB}=$ Carbonate bound zinc, $\mathrm{RES}=$ Residual zinc. 
Table 6. Correlation coefficient (r) between zinc fractions in soil after harvest of wheat (60 DAS)

\begin{tabular}{lcccccccc}
\hline Zinc Fractions & WSEX & OC & MnOX & AFeOX & CFeOX & CARB & RES & DTPA-Available \\
\hline WSEX & 1.000 & $0.862^{* *}$ & $0.752^{* *}$ & $0.819^{* *}$ & $0.821^{* *}$ & $0.936^{* *}$ & $0.791^{* *}$ & $0.943^{* *}$ \\
OC & & 1.000 & $0.906^{* *}$ & $0.996^{* *}$ & $0.958^{* *}$ & $0.883^{* *}$ & $0.926^{* *}$ & $0.850^{* *}$ \\
MnOX & & & 1.000 & $0.909^{* *}$ & $0.918^{* *}$ & $0.890^{* *}$ & $0.930^{* *}$ & $0.659^{*}$ \\
AFeOX & & & & 1.000 & $0.956^{* *}$ & $0.851^{* *}$ & $0.921^{* *}$ & $0.815^{* *}$ \\
CFeOX & & & & & 1.000 & $0.851^{* *}$ & $0.954^{* *}$ & $0.795^{* *}$ \\
CARB & & & & & & 1.000 & $0.890^{* *}$ & $0.810^{* *}$ \\
RES & & & & & & & 1.000 & $0.688^{*}$ \\
DTPA-Available & & & & & & & & 1.000 \\
\hline
\end{tabular}

* and $* *$ significant at $\mathrm{P}=0.05$ and $\mathrm{P}=0.01$, respectively; where, DAS=Days After Sowing, WSEX=Water soluble + exchangeable zinc, $\mathrm{OC}=$ Organically complexed zinc, $\mathrm{MnOX}=$ Manganese oxide bound zinc, $\mathrm{AFeOX}=\mathrm{Amorphous}$ iron oxide bound zinc, $\mathrm{CFeOX}=$ Crystalline iron oxide bound zinc, $\mathrm{CARB}=$ Carbonate bound zinc, RES=Residual zinc.

Table 7. Correlation coefficient (r) between different fractions of zinc in soil after harvest of maize (60 DAS)

\begin{tabular}{lcccccccc}
\hline & WSEX & OC & MnOX & AFeOX & CFeOX & CARB & RES & $\begin{array}{c}\text { DTPA-Av } \\
\text { ailable }\end{array}$ \\
\hline WSEX & 1.000 & $0.839^{* *}$ & 0.406 & 0.441 & 0.048 & $0.799^{* *}$ & $0.785^{* *}$ & $0.915^{* *}$ \\
OC & & 1.000 & $0.816^{* *}$ & $0.709^{* *}$ & 0.326 & $0.911^{* *}$ & $0.978^{* *}$ & $0.895^{* *}$ \\
$\mathrm{MnOX}$ & & & 1.000 & $0.772^{* *}$ & 0.532 & $0.801^{* *}$ & $0.872^{* *}$ & 0.549 \\
$\mathrm{AFeOX}$ & & & & 1.000 & $0.894^{* *}$ & $0.796^{* *}$ & $0.747^{* *}$ & 0.343 \\
$\mathrm{CFeOX}$ & & & & & 1.000 & 0.484 & $0.385^{* *}$ & -0.101 \\
$\mathrm{CARB}$ & & & & & & 1.000 & $0.935^{* *}$ & $0.754^{* *}$ \\
RES & & & & & & 1.000 & $0.836^{* *}$ \\
DTPA-Av & & & & & & & & 1.000 \\
ailable & & & & & & & & \\
\hline
\end{tabular}

$*$ and $* *$ significant at $\mathrm{P}=0.05$ and $\mathrm{P}=0.01$, respectively; where, DAS=Days After Sowing, WSEX=Water soluble + exchangeable zinc, OC=Organically complexed zinc, MnOX=Manganese oxide bound zinc, $\mathrm{AFeOX}=$ Amorphous iron oxide bound zinc, $\mathrm{CFeOX}=$ Crystalline iron oxide bound zinc, $\mathrm{CARB}=$ Carbonate bound zinc, RES=Residual zinc.

Table 8. Correlation coefficient (r) between fractions of zinc in soil and plant (60 DAS)

\begin{tabular}{ccccccccc}
\hline & \multicolumn{7}{c}{ Zn fractions in soil after harvest of crop } \\
\cline { 2 - 9 } & WSEX & OC & MnOX & AFeOX & CFeOX & CARB & RES & DTPA-Available \\
\hline Zn in wheat plant & $0.935^{* *}$ & $0.752^{* *}$ & 0.526 & $0.703^{* *}$ & $0.676^{*}$ & $0.773^{* *}$ & $0.591^{*}$ & $0.973^{* *}$ \\
Zn in maize plant & $0.913^{* *}$ & $0.825^{* *}$ & 0.442 & 0.224 & -0.221 & $0.693^{*}$ & $0.761^{* *}$ & $0.989^{* *}$ \\
\hline
\end{tabular}

* and ** significant at $\mathrm{P}=0.05$ and $\mathrm{P}=0.01$, respectively; where, DAS=Days After Sowing, WSEX $=$ Water soluble + exchangeable zinc, OC=Organically complexed zinc, MnOX=Manganese oxide bound zinc, $\mathrm{AFeOX}=\mathrm{Amorphous}$ iron oxide bound zinc, $\mathrm{CFeOX}=$ Crystalline iron oxide bound zinc, $\mathrm{CARB}=$ Carbonate bound zinc, RES=Residual zinc. 